\title{
Factors influencing willingness to participate in multi-stakeholder platform by smallholder farmers in Northern Ghana: implication for research and development
}

\author{
Edward Martey, ${ }^{*}$ Prince M Etwire, Alexander N Wiredu and Wilson Dogbe
}

\author{
* Correspondence: \\ marteywayo2@yahoo.com \\ CSIR-Savanna Agricultural Research \\ Institute, Nyankpala, P.O. Box TL 52, \\ Tamale, Ghana
}

\section{Abstract \\ Innovation platforms are established to facilitate open communication and collaboration among various actors usually within a value chain to promote collective resource management. The concept of innovation platform as a strategy of entry point for operationalization, validation and dissemination of agricultural technology have received much attention in recent times among researchers in Ghana. However, very limited information exists on the factors that influence willingness of farmers' participation. The present study identified the factors influencing willingness to participate in innovation platform and also tested the level of agreement among the identified constraints associated with participation using the Probit model and Kendall's coefficient of concordance respectively. Data for the study was collected from a cross sectional primary observations of 250 smallholder rice farmers in northern Ghana. The study observes, inter alia, that age of household head, household size and household income significantly influenced willingness to participate on the platform. The Kendall's coefficient of concordance value indicated that there was 21 percent agreement between the rankings of the participation constraints faced by the sampled rice farmers. Income-earning and younger household heads must be targeted coupled with situation of the platforms close to smallholder farmers to encourage participation.}

Keywords: Multi-stakeholder platform; Constraint; Probit; Kendalls coefficient of concordance; Northern Ghana

\section{Background}

Development research in Africa has centered mainly on smallholder commercialization as a way of ensuring food security and economic growth. Agriculture in most African economies is on smallholder basis. In sub-Saharan Africa, Asia and the Pacific, the agriculture-dependent population is over 60\%, while in Latin America and highincome economies the proportions are estimated at $18 \%$ and $4 \%$, respectively (World Bank 2006). Most of the smallholder farmers in sub-Saharan Africa are confronted with multifaceted challenges. These problems require several interventions such as institutional reforms that facilitate efficient rural service delivery, development of markets, creation of physical infrastructure, and government policies that are supportive while ensuring a stable and conducive political environment. Smallholder farmers 
require systems that are responsive to their needs: access to markets, market information, market intelligence and effective farmer organization as the agricultural sector in developing countries transforms towards commercialization.

According to Pingali et al. (2005), smallholder farmers in most developing economies find it difficult to participate in markets because of numerous constraints and barriers. These are mostly reflected in the hidden costs that make it difficult to access input and output markets. Transaction costs are the embodiment of access barriers to market participation for most resource-poor smallholders (Delgado 1999; Holloway et al. 2000). A fundamental transaction cost these farmers face is the cost of obtaining information (Shepherd 1997). Though neoclassical economists essentially assume that information is costless, this assumption does not match reality, especially in developing countries (Stiglitz 1988). The fact that information is not costless has important implications for contracts and transactions, as has been pointed out in work pioneered by Coase (1937) and later expanded in Coase (1960). Commercialization studies such as Goetz (1992), Key et al. (2000) and Makhura et al. (2001) have identified high transaction costs as one of the key reasons for smallholder farmers' failure to participate in markets. Most are located in remote areas with poor transport, market infrastructure and lack of reliable information on markets and potential exchange partners. In some instances, these transaction costs are so high that markets can be said to be 'missing' (Omamo 1998; Key et al. 2000). The adoption and use of multi-stakeholder platform (MSP) in most recent times has the potential to address the high transaction cost incurred by smallholder farmers with regard to market information.

The three most targeted regions in Ghana for most agricultural development projects are Northern, Upper East and Upper West Regions. The regions are inundated with high levels of food insecurity and poverty due to over-reliance on rain-fed agriculture under low farm input conditions. About half of the population of the area face annual food deficit and are net buyers of food (GSS 2008). Nearly 80 percent of the population depends on subsistence agriculture with very low productivity and low farm income (MoFA 2010). Several programmes have been designed over the years especially in the rice sector to address the food insecurity and poverty levels in northern Ghana. One of the major interventions was the Multinational NERICA Rice Dissemination Project which sought to contribute to poverty reduction and food security in Ghana through capacity building, technology transfer and production support.

The Commercial Development of Farmer Based Organization (CDFO) of the Millennium Challenge Account (MCA) Programme was an intervention in addressing one of the objectives of the Food and Agriculture Sector Development Policy II (FASDEP II). The objective was to enhance increase competitiveness and integration of farmers into domestic and international markets. To overcome the market constraints of producers, farmers were organized into Farmer-Based Organization (FBO) to access credit and engage in bulk purchase and group marketing to lower the transaction cost they incur in marketing. Agricultural Business Centres (ABCs) were established to enable farmers to access market information on prices, standards and advisory services. The other component of the MCA program sought to strengthen input delivery systems and financial institutions that advances credit to farmers. The intervention however failed to use the integrated approach such as innovation platform to address the marketing problems of the farmers. Most of these interventions fail the test of sustainability after the completion of the entire project. 
In an attempt to address the weak linkages among the rice value chain actors as well as increase in rice production in Ghana, the Africa Rice Center (AfricaRice) in collaboration with the Savanna Agricultural Research Institute of the Council for Scientific and Industrial Research (CSIR-SARI) established two Multi-Stakeholder Platforms (MSP) in two rice development hubs ${ }^{a}$ in northern Ghana. The Multi-Stakeholder Platform establishment was used to facilitate open communication and collaboration among various actors within the value chain to promote collective resource management. The platform serves as a point of entry, operationalization, validation and dissemination of agricultural technologies. Sustainable development of the rice sector and the rice value chain through an MSP approach prompts key stakeholders to identify and prioritize their needs, concerns, constraints, and vision for key activities and interventions. They also act as a governing entity that coordinates decision-making at local, regional, and national levels regarding rice sector development in the long run. The MSP was also intended to assist farmers overcome their production, marketing and post-production challenges in the regions.

In northern Ghana, the MSP for the rice sector consists of researchers, producers, processors, traders, financial institutions, input dealers, tractor operators and policy makers. The platform brings together all the necessary stakeholders of the rice sector to dialogue on ways of increasing rice production to enhance food security with Savanna Agricultural Research Institute providing the backstopping. Introduction, operationalization, validation and dissemination of all rice development programmes in the region occurs on the platform. All the various actors play a significant role in ensuring a boost in the rice sector as well as strengthening of the rice value chain. Most established platforms are confronted with some challenges which include meeting and sustaining participants' interest, effective participation and collaboration, conflict resolution and collective action.

\section{Problem statement and justification}

Despite the benefits of the platform especially in transforming the rice value chain system, it is critical to identify the potential factors that are likely to influence farmers' willingness to participate in such a platform as well as the constraints associated with participation. Currently, there is no documented evidence of the factors and constraints limiting farmers' willingness to participate on innovative platforms especially in the study area. It is against this backdrop that the present study attempts to fill the gap in knowledge. The documented factors and constraints will serve as the basis for addressing the sustainability issues regarding the intervention. The study contributes significantly to the scanty literature on MSP and also serve as a guide for future implementation of similar platforms in other parts of Africa. Finally, facilitators of MSP and rice development programmes will benefit from the knowledge generated by the study.

\section{Literature review}

\section{Concept and empirical evidence of multi-stakeholder platforms}

The term multi-stakeholder platform (MSPs) describes processes which aim to bring together all major stakeholders in a new form of communication, decision-finding (and 
possibly decision-making) on a particular issue. They are also based on recognition of the importance of achieving equity and accountability in communication between stakeholders, involving equitable representation of three or more stakeholder groups and their views. They are based on democratic principles of transparency and participation, and aim to develop partnerships and strengthened networks between stakeholders. MSPs cover a wide spectrum of structures and levels of engagement. They can comprise dialogues on policy or grow into consensus-building, decision-making and implementation of practical solutions. The exact nature of any such process will depend on the issues, its objectives, participants, scope, time lines, etc. (www.earthsummit2002.org).

Multi-stakeholder platforms were first proposed in the context of natural resource management, where stakeholders share a common-pool resource, such as access to water in a river basin, and the platform contributes to the collective management of the resource (Rölling et al. 2002). A platform has value for stakeholders, because they are, or may become, interdependent. Interdependence can create tension, conflict, maneuvering to seek advantage and even group displacement. But it also opens opportunities for mutual understanding, building confidence, social learning and joint action (Rölling et al. 2002). The platform makes possible actions that none of the members could have achieved on their own. Because of its complex membership and potential for conflict, a platform is likely to require facilitation and may have a lengthy initial phase of mutual learning and role definition, before it can get down to business (Thiele et al. 2005).

Most value chain does not frequently use the approach of platforms. Several studies including a recent overview of collective action for small farmer market access considered small farmer organizations without mentioning platforms (Markelova et al. 2009). An exception is the study by Vellema et al. (2009), which analyses the oil seed subsectoral platform in Uganda. A platform can perform three different, but interlinked, functions in a value chain. First, it can create a space for learning and joint innovation, as an innovation intermediary or broker. Second, it can perform a governance function within the value chain to improve coordination of business activities by actors and reduce transaction costs. Finally, a platform can perform advocacy functions to secure policy change or influence.

Value chain governance may be provided by: (a) market mechanisms, (b) hierarchical non-market mechanisms and (c) by non-market-based voluntary coordination between actors of a collective action type (Markelova et al. 2009). Dorward et al. (2009), writing from a New Institutional Economics perspective, noted that coordination provided through different non-market mechanisms can help market actors reduce transaction costs and escape the low-level equilibrium trap associated with underdeveloped economies, as a weak institutional environment and high transaction risks limit investment opportunities.

Countries that have witnessed success in overcoming marketing constraints by using the MSP include Peru, Bolivia and Ecuador. The platform Cadinas Agricolas Productivas de Calidad (CAPAC) in Peru which focused on native potatoes grown largely by poorer farmers primarily for home consumption or local markets has been instrumental in providing transparent information on price and volumes. The CAPAC has also assumed an important role in market governance by linking farmers' native potato production to Frito-Lay and Ayllin Papa through intermediary NGOs (Thiele et al. 2011). 
The platform Andino Boliviana in Bolivia played an important facilitating and coordinating role so as to link farmers' organizations with exporting companies, contributing to the supply of quality chun o for the export market (Thiele et al. 2011). In Ecuador, Chimborazo platform played the most extensive role in market governance. The platform developed and monitored production plans with farmer quotas by market catchment areas to smooth the supply of potatoes to clients. In addition, the platform empowered farmers' organizations and associations to assume a greater leadership role which led to the creation of CONPAPA (Consorcio de Pequen os Productores de Papa, Consortium of Small Potato Producers), which from late 2006 took over the technical assistance functions, production planning, bulking up and marketing functions that the Chimborazo platform had previously performed (Thiele et al. 2011).

Evidence from the Innovation Platform for Technology Adoption (IPTA) in Burkina Faso indicates that maize producers and processors are making profit on their investments and processors are making a difference of only CFA 1.00 over and above the profit margin of producers. Farmers are also increasing the area under maize cultivation due to a guaranteed market as provided by the platform.

Most of the literature reviewed on MSP is descriptive in presentation with little information on specific quantifiable factors that influence willingness of participation. However, the current study used a regression model to analyze farmers' willingness to participate in MSP by drawing lessons from the reviewed literature. Future studies can look at the extent of participation in MSP on household income and food security.

\section{Methods}

\section{Study area}

Northern Ghana consists of Northern, Upper East and Upper West Regions. The vegetation is a typical Guinea Savannah type characterized by drought-resistant grasses and trees. The area plays an important role in agriculture and is normally referred to as the grain basket of the country. It shares borders with Republic of Togo to the east, Ivory Coast to the west and Burkina Faso to the north. Within the country, the northern Ghana is bordered by Volta region to south east and Brong-Ahafo region to the south east. Geographically, the three regions are between longitude $8^{\circ} 46^{\prime} 01.88^{\prime \prime} \mathrm{N}$ and $10^{\circ}$ $58^{\prime} 34^{\prime \prime} \mathrm{N}$ and latitude $2^{\circ} 45^{\prime} 45.40^{\prime \prime} \mathrm{W}$ and $0^{\circ} 32^{\prime} 59.95^{\prime \prime} \mathrm{E}$ and covers a total land area of $97,666 \mathrm{~km}^{2}$ with an estimated population of $3,317,478$. The major crops cultivated in the area are rice, maize, sorghum, millet, groundnut, beans and Shea butter. Livestock and poultry production are also important ventures for most households. The study area consists of two main rice development hubs namely the Navrongo and Savelegu hubs.

\section{Data and sampling technique}

The study was conducted between August and September, 2012. The basic information for the analysis was obtained from primary data collected with the aid of a structured questionnaire. A total of 250 smallholder rice producers were systematically selected and interviewed. The selection of the rice producers followed a multi-stage systematic random sampling technique. In the first stage, two (2) rice hubs in Navrongo and Savelugu districts were purposively selected. Secondly, five (5) communities each were 
randomly selected from a list of rice producing communities in each of the rice hubs. Within the selected communities in each of the hubs, 26 and 24 rice producers were further selected from a list of rice producers in the Navrongo and Savelugu selected communities respectively (Table 1). In addition to the survey, key informants interviews and focus group discussion were conducted to augment the household survey.

\section{Probit model}

The probit regression model was employed to quantify the factors that determine the willingness of farmers to participate in multi-stakeholder platform due to the dichotomous nature of the dependent variable. The justification for the use of the probit model over the logit model is as a result of its ability to constrain the utility value of the decision to join variable to lie within 0 and 1 , and its ability to resolve the problem of heteroscedasticity (Asante et al. 2011). Willingness to participate in MSP (Y) was captured as a dummy variable with the value of 1 assigned to a farmer who is willing to participate and 0 for otherwise. Following from Greene (2003), the binary probit for the two choice models can be written as;

$$
Y_{i}^{*}=\left\{\begin{array}{l}
1 \text { if } Y_{i}^{*}>Y \\
0 \text { if } Y_{i}^{*} \leq 0
\end{array}\right.
$$

The probit model is given by:

$$
P\left(Y=\frac{1}{X}\right)=F(X B)=\frac{1}{\sqrt{2 \pi}} \int_{-\infty}^{X B} e^{\frac{-(X B)^{2}}{2}} d x
$$

where:

$$
\begin{aligned}
& X=\left(1, x_{1 i}, x_{2 i}, \ldots \ldots, x_{k i}\right) \\
& \beta^{\prime}=\left(\beta_{0}, \beta_{1}, \ldots \ldots \ldots \ldots, \beta_{k}\right)
\end{aligned}
$$

Specifically, the empirical model for determining the willingness to participate in in MSP is specified in equation as follows (5).

$$
\begin{aligned}
Y_{i}=\beta_{0} & +\beta_{1} \text { Age }+\beta_{2} \text { Gend }+\beta_{3} \text { Mari }+\beta_{4} \text { HSize } 5 \text { t) } \beta_{5} \text { Edu }+\beta_{6} \text { Assoc }+\beta_{7} \text { Lab } \\
& +\beta_{8} \text { FarmDec }+\beta_{9} \text { Dist }+\beta_{10} \text { Inc }+\mu_{i}
\end{aligned}
$$

Where $Y_{i}$ and $\mu_{i}$ represents willingness to participate in MSP and the error term respectively. The set of potential explanatory variables, definitions and their a priori expectations are presented in Table 2.

The marginal effect of the variables is calculated using the formula:

$$
\text { Marginal effects }=B_{i} \varnothing(Z) \text { where } B_{i} \text { are the coefficient of the variable }
$$

Table 1 Sampling frame

\begin{tabular}{lll}
\hline Rice hub & Communities & Households \\
\hline Navrongo & 5 & 130 \\
Savelegu & 5 & 120 \\
\hline Total & 10 & 250 \\
\hline
\end{tabular}


Table 2 Explanatory variables for the probit model

\begin{tabular}{llc}
\hline Variable & Definition & $\begin{array}{c}\text { Expected } \\
\text { sign }\end{array}$ \\
\hline Gender (Gend) & 1 if male and 0 otherwise & $+/-$ \\
Age (Age) & Age of household head in years & - \\
Marital status (Mar) & 1 if married and 0 otherwise & + \\
Education (Edu) & Number of years of formal education & + \\
Household size (HSize.) & Number of household members that assist with farming & + \\
Land availability (Lab) & Total land size cultivated in 2012 & + \\
Total income (Inc.) & Total income earned from rice sales in 2012 & + \\
Membership of association (Assoc.) & 1 if farmer belongs to FBO and 0 otherwise & - \\
Distance (Dist.) & Distance from farmers house to the meeting place in km & + \\
Major farming decision (FarmDec) & 1 if household head makes decision alone and 0 otherwise & $+/-$ \\
\hline
\end{tabular}

Where $B_{i}$ represents the estimated coefficients and the $\varnothing(Z)$ is the cumulative normal distribution value associated with the mean dependent variable from the Probit estimation.

Table 2 shows the set of potential explanatory variables that are expected to explain variation in willingness to participate in MSP and their a priori expectations.

\section{Description of explanatory variables}

Gender is expected to have a significant effect on participation in MSP. Males are expected to have higher willingness of participation in MSP relative to females. Female farmers usually lack access to agricultural resource that enhances their participation in social and innovation platforms. Age is expected to influence willingness to participate in MSP negatively. It is a proxy measure of experience and availability of resources. According to Etwire et al. (2013), younger farmers are usually innovative, risk loving and may want to try new concepts. Marital status allows an individual to have access to information and resource. It is expected that household head that are married are more willing to participate on the platform. Nnadi and Akwiwu (2008) noted that marriage increases a farmer's concern for household welfare and food security which is therefore likely to have a positive effect on their decision to participate in an agricultural project.

Education is posited to have a positive effect on willingness to participate on the platform. Education enables an individual to make independent choices and to act on the basis of the decision, as well as increase the tendency to co-operate with other people and participate in group activities (Enete and Igbokwe 2009; Southworth and Johnston 1967; Schultz 1945 and Ofori 1973). It is also possible that education could increase the chances of the household head earning non-farm income. This could reduce the household dependency on agriculture and thus participation on the platform. Household size is expected to positively influence farmers' willingness to participate on the platform. Household size serves as a form of family labour and compliments the effort of the household heads on the farm (Martey et al. 2013). The availability of family labour provides the household head the opportunity to share responsibility and save time for other useful activities like the MSP. Also, larger households spend more on food and other household needs. The higher expenditure associated with larger 
households sizes tend to make them more resource constrained and hence the need for external support (Martey et al. 2013).

Land availability has an indirect positive effect on farmers' willingness to participate. Household heads with more land are able to produce more ceteris paribus and earn higher income to overcome the transportation constraint as well as financial demands of the platform. Most researchers have found a positive relationship between farm size and decision to join or adopt (Adimado 2001; Kheralla et al. 2001; Langyintuo and Mekuria 2005). Other studies such as Mussei et al. (2001), and Gockowski and Ndoumbe (2004) found a negative relationship between farm size and decision to join or adopt. The coefficient of this variable can be either positive or negative. A household head that earns higher income from rice sales will be more willing to participate on the platform. Higher income household heads are able to meet the financial demands of any group they belong to relative to lower income households. Household head membership of an association/group increases access to information which is important to production and marketing decisions (Olwande and Mathenge 2010). Most farmer groups engage in group marketing, bulk purchasing of inputs and credit provision for its members. It is therefore expected that household head membership of association/ group will positively affect willingness to participate on the platform. Distance serves as a major cost constraint to willingness to participate on the platform. Household heads residing farther away from the meeting place may find it difficult to effectively participate especially in situations where they do not have means of transport.

\section{The Kendall's coefficient of concordance}

The Kendall's concordance analysis was used to test for the agreement between the ranked constraints of willingness to participate on the MSP. It establishes the extent of disagreements and agreements among responses. The Kendall's coefficient of concordance (W) is the measure of the degree of agreement among $m$ set of $n$ ranks. $W$ is an index that measures the ratio of the observed variance of the sum of ranks to the maximum possible variance of sum of ranks. If the rankings are in perfect agreement, the variability among sums will be a maximum (Mattson 1986). Computing the total rank score for each constraint and objective, the constraint and objective with the least score is ranked as the most pressing whilst the one with the highest score is ranked as the least pressing. The total rank score computed is then used to calculate for the coefficient of concordance $(W)$, to measure the degree of agreement in the rankings (Edwards 1964). The formula for the coefficient of concordance $\mathrm{W}$ is then given by:

$$
W=\frac{\left(\sum T^{2}-\left(\sum T\right)^{2} / n\right) / n}{m^{2}\left(n^{2}-1\right) / 12}
$$

The formula is further simplified as follows:

$$
W=\frac{12\left[\sum T^{2}-\left(\sum T\right)^{2} / n\right]}{n m^{2}\left(n^{2}-1\right)}
$$


Where;

$\mathrm{T}=$ sum of ranks for each thing being ranked.

$\mathrm{m}=$ number of rankings (smallholder farmers) and

$\mathrm{n}=$ number of things (factors) being ranked

The following hypothesis was tested for the potential constraints as follows:

$\mathrm{H}_{0}$ : There is no agreement among the constraints faced by smallholder rice farmers' willingness to participate on the MSP.

$\mathrm{H}_{1}$ : There is agreement among the constraints faced by smallholder rice farmers' willingness to participate on the MSP.

The Coefficient of concordance $W$ was tested for significance using the F distribution.

\section{Results and discussion}

\section{Multi-stakeholder platform participation by smallholder farmers}

Participation in multi-stakeholder platform based on gender revealed that $59 \%$ of the sampled male-headed households whereas $43 \%$ of the female-headed households were members on the platform (Table 3). The higher representation by males relative to females on the platform was as a result of unlimited access to agricultural resources that enhances participation in social platforms. Easy access to agricultural resource by maleheaded households makes them more adaptive to new innovations and technology compared to female-headed households.

Willingness to participate in MSP based on gender revealed that $82 \%$ (120) of maleheaded households were willing to participate on the platform. Female headed households were more willing to participate on the platform as represented by $92 \%$ of the sampled farmers (Table 4). In northern Ghana, it is mostly common to see women group flourishing. Female-headed households are more likely to adopt a technology or innovation that will enhance their productivity and income. This finding implies that gender must be critically considered in the selection of the participants. Marketing of agricultural produce is mostly dominated by women who are also faced with myriads of marketing constraints such as lower market price and higher transaction cost. The opportunity offered by the platform as a way of overcoming these constraints as well as knowledge sharing could explain for the higher willingness of participation on the part of female producers.

Table 5 shows that $52 \%$ (92) of the sampled households who are members of the MSP are within the age bracket of less than or equal to 40 years $(\leq 40)$ whereas $46 \%$

Table 3 Membership of MSP by gender

\begin{tabular}{lllllll}
\hline \multirow{2}{*}{$\begin{array}{l}\text { Membership } \\
\text { of MSP }\end{array}$} & \multicolumn{2}{l}{ Gender of household head } & & & \\
\cline { 2 - 7 } & Male & Percentage & Female & Percentage & Total & Percentage \\
\hline No & 61 & 41.50 & 59 & 57.30 & 120 & 48.00 \\
Yes & 86 & 58.50 & 44 & 42.70 & 130 & 52.00 \\
\hline Total & 147 & 100.00 & 103 & 100.00 & 250 & 100.00 \\
\hline
\end{tabular}

Source: Author's Household Survey Data (2012). 
Table 4 Willingness to participate in MSP by gender

\begin{tabular}{lllllll}
\hline $\begin{array}{l}\text { MSP } \\
\text { participation }\end{array}$ & \multicolumn{6}{l}{ Gender of household head } \\
\cline { 2 - 7 } & Male & Percentage & Female & Percentage & Total & Percentage \\
\hline Yes & 120 & 81.60 & 95 & 92.20 & 215 & 86.00 \\
No & 27 & 18.40 & 8 & 7.80 & 35 & 14.00 \\
\hline Total & 147 & 100.00 & 103 & 100.00 & 250 & 100.00 \\
\hline
\end{tabular}

Source: Author's Household Survey Data (2012).

and $73 \%$ of household head falls within the age category of 41 to 60 years and greater than 60 years ( $>60$ years) respectively. In absolute terms majority of the members of the MSP are within the economically active age group of the country. The result has implication on technology adoption and sustainability. Relatively younger household heads should be targeted for the innovation platform approach to enhancing food security and reduction in poverty. Younger household heads are more likely to adopt technology and innovations relative to older household heads (Enete and Igbokwe 2009).

The results in Table 6 also show high level of willingness of participation across all the age categories. The willingness of participation response is relatively higher among the economically active age group (41-60 years) and older age category ( $>60$ years) relative to the younger age group category ( $\leq 40$ years) (Table 6 ). Willingness to participate on the MSP was highly correlated with age where the older age category ( $>60$ years) recorded the highest percentage. The result implies that there is opportunity to reach out to other smallholder farmers irrespective of the age. For sustainability of the platform, it is more expedient for the facilitators to target both the young and the economically active age group category.

Fifty-five (55) percent of the household heads belonging to a Farmer-Based Organization (FBO) were members of the MSP whilst 50\% of non-members of FBO household head were also members of the platform (Table 7). Farmer Based Organization is one of the main channels for reaching out to numerous farmers for collective actions. It also serves as a platform for capacity building, marketing, bulk purchasing and advocacy. Increase in MSP participation by members of FBO can only be realized through consistent education of farmers on the concept of the MSP.

Members and non-members of FBO were more willing to participate in the MSP (Table 8). About $87 \%$ of household heads belonging to a FBO were willing to participate in the MSP whilst $86 \%$ of non-members of $\mathrm{FBO}$ were also willing to join the platform. Previous benefits from FBOs and the need for social networks may have influenced the willingness decision of household heads in northern Ghana.

Table 5 Membership of MSP by age

\begin{tabular}{lllllllll}
\hline $\begin{array}{l}\text { Membership } \\
\text { of MSP }\end{array}$ & \multicolumn{6}{l}{ Household head age (Years) } \\
\cline { 2 - 10 } & $\mathbf{5} \mathbf{4 0}$ & $\mathbf{\%}$ & $\mathbf{4 1 - 6 0}$ & $\mathbf{\%}$ & $\mathbf{7 6 0}$ & $\mathbf{\%}$ & Total & $\mathbf{\%}$ \\
\hline No & 84 & 47.70 & 32 & 54.20 & 4 & 26.70 & 120 & 48.00 \\
Yes & 92 & 52.30 & 27 & 45.80 & 11 & 73.30 & 130 & 52.00 \\
\hline Total & 176 & 100.00 & 59 & 100.00 & 15 & 100.00 & 250 & 100.00 \\
\hline
\end{tabular}

Source: Author's Household Survey Data (2012). 
Table 6 Willingness of participation based on age

\begin{tabular}{lllllllll}
\hline MSP & \multicolumn{6}{l}{ Household head age (Years) } \\
\cline { 2 - 10 } & $\mathbf{4} \mathbf{4 0}$ & $\mathbf{\%}$ & $\mathbf{4 1 - 6 0}$ & $\mathbf{\%}$ & $\mathbf{7 6 0}$ & $\mathbf{\%}$ & Total & $\mathbf{\%}$ \\
\hline Yes & 149 & 84.70 & 52 & 88.10 & 14 & 93.30 & 215 & 86.00 \\
No & 27 & 15.30 & 7 & 11.90 & 1 & 6.70 & 35 & 14.00 \\
\hline Total & 176 & 100.00 & 59 & 100.00 & 15 & 100.00 & 250 & 100.00 \\
\hline
\end{tabular}

Source: Author's Household Survey Data (2012).

\section{Determinants of multi-stakeholder platform participation}

The probit model was used to estimate the parameters of the determinants of willingness to participate on the multi-stakeholder platform by smallholder farmers in northern Ghana. The E-views software was used to estimate these parameters as well as the marginal effects. The McFadden R-squared value indicates that 36 percent of the variation in the willingness to participate on the platform was explained by the independent variables. The significant likelihood ratio (LR) of 73.43 with 10 degrees of freedom indicates that at least one of the variables in the model had a significant effect on farmers' willingness to participate on the platform and that the explanatory variables jointly influence the farmers' willingness of participation on the platform (Table 9). Farmers' willingness to participate on the multi-stakeholder platform was significantly determined by age of the household head, household size and household income. Numerically and statistically, age was the most influential determinant of willingness to participate in MSP. Details of the regression result is presented in Appendix 1.

Age of the household head was significantly associated with a lower probability of willingness to participate on the platform. The probability of willingness to participate in MSP decreases by 7.6 percent for every additional year added to the age of the household head (Table 9). It can be inferred from the result that younger household heads were more willing to participate on the platform than older household heads. Older household heads are normally experienced in farming and may have more social networks which enhance their farming business thus will be more reluctant in joining the platform. Secondly, older household heads may not have the motivation to join such a platform as the level of willingness to adopt innovation declines with age. The result is consistent with Ayamga (2006) who found that as age increases, the probability of a farmer to participate in microcredit programmes in northern Ghana, decreases. However, the finding is contrary to Asante et al. (2011). They established a positive relationship between age and farmers' decision to join farmer based organization in Ghana.

Household size was significantly associated with a higher probability of farmer's willingness to participate on the platform. The probability of farmer's willingness to participate increases by 3.3 percent for every additional member added to the household

Table 7 Membership of MSP by membership of FBO

\begin{tabular}{lllllll}
\hline $\begin{array}{l}\text { Membership } \\
\text { of MSP }\end{array}$ & \multicolumn{2}{l}{ Membership of FBO } \\
\cline { 2 - 7 } & Yes & Percentage & No & Percentage & Total & Percentage \\
\hline No & 51 & 45.50 & 69 & 50.00 & 120 & 48.00 \\
Yes & 61 & 54.50 & 69 & 50.00 & 130 & 52.00 \\
\hline Total & 112 & 100.00 & 138 & 100.00 & 250 & 100.00 \\
\hline
\end{tabular}

Source: Author's Household Survey Data (2012). 
Table 8 Willingness of participation in MSP by membership of FBO

\begin{tabular}{lllllll}
\hline $\begin{array}{l}\text { MSP } \\
\text { participation }\end{array}$ & \multicolumn{2}{l}{ Membership of FBO } \\
\cline { 2 - 7 } & Yes & Percentage & No & Percentage & Total & Percentage \\
\hline Yes & 97 & 86.60 & 118 & 85.50 & 215 & 86.00 \\
No & 15 & 13.40 & 20 & 14.50 & 35 & 14.00 \\
\hline Total & 112 & 100.00 & 138 & 100.00 & 250 & 100.00 \\
\hline
\end{tabular}

Source: Author's Household Survey Data (2012)

(Table 9). Household size represents the supply of family labour for production activities. Farming in the tropics is mostly rain-fed and labour-intensive. A household head with large household size will be more willing to participate on the platform because of excess or additional labour to work on the farm whilst absent from the farm. The demand of economically inactive household members coerces household heads to search for innovative ways to improve upon their farming business.

Willingness to participate on the platform was significantly influenced by household income. The likelihood of farmers' willingness to participate on the platform increases by 0.04 percent for every additional increase in household income (Table 9). Transportation cost is one of the major constraints in MSP participation. Household head with higher income are able to overcome this cost and also make financial contributions in the form of dues and levy as demanded by the platform to ensure its sustainability. Household heads with higher income may necessarily participate on the platform to widen their social networks. Asante et al. (2011) also established a positive relationship between farmers' income and willingness to join Farmer Based Organizations. According to their findings, increasing farmers' income by one Ghana cedi increases the likelihood of joining FBOs by $0.026 \%$.

\section{Constraints in multi-stakeholder platform participation}

The constraints of smallholder rice farmers identified during the survey are presented in Table 10. The Kendall's 'W' was found to be 0.205 and significant at $1 \%$ level. The

Table 9 Determinants of willingness of MSP participation

\begin{tabular}{|c|c|c|c|}
\hline \multirow[t]{2}{*}{ Variable } & \multicolumn{3}{|c|}{ Estimated result of probit model } \\
\hline & Coefficient & Std error & Marginal effect \\
\hline Age of household head & -0.0688 & 0.0106 & $-0.0757^{* * *}$ \\
\hline Gender & 0.0001 & 0.2592 & 0.0002 \\
\hline Marital status of household & 0.0185 & 0.6966 & 0.0203 \\
\hline Household size & 0.0302 & 0.0174 & $0.0332^{*}$ \\
\hline Years of education of household head & 0.0616 & 0.0463 & 0.0678 \\
\hline Membership of association & 0.3354 & 0.2533 & 0.3689 \\
\hline Land availability & -0.0802 & 0.0561 & -0.0882 \\
\hline Major farming decision & -0.0628 & 0.3570 & -0.0691 \\
\hline Distance to meeting place & -0.0456 & 0.0663 & -0.0501 \\
\hline Household income & 0.0004 & 0.0002 & $0.0004^{* *}$ \\
\hline Constant & 3.5952 & 0.9925 & 3.9547 \\
\hline Number of Observations & 250 & Log likelihood & -64.5260 \\
\hline Mean dependent var. & 0.8600 & McFadden R-squared & 0.3626 \\
\hline
\end{tabular}

Source: Regression Estimation from Author's Household Survey Data (2012) ${ }^{* * *} p<0.01,{ }^{* *} p<0.05$ and ${ }^{*} p<0.10$. 
Table 10 Constraints in multi-stakeholder platform participation

\begin{tabular}{ll}
\hline Identified constraints & Mean rank \\
\hline Distance to meeting place & 3.14 \\
Confliction of meeting days with market days & 3.18 \\
Information dissemination regarding meeting days & 3.70 \\
Risk & 3.77 \\
Weather condition & 3.82 \\
Means of transport & 4.38 \\
Farming season for holding meeting & 6.00 \\
\hline Number of observation & 250 \\
Kendall's W & 0.205 \\
Chi-square & 307.110 \\
Df. & 6 \\
Assymp. Sig. & 0.000 \\
\hline
\end{tabular}

Source: Estimation from Author's Household Survey Data (2012).

null hypothesis was rejected in favour of the alternate hypothesis which stated that there is agreement among the constraints faced by smallholder farmers in MSP participation. The Kendall's 'W' of 0.205 indicates that there was 21 percent agreement between the respondents in the ranking of the constraints faced by smallholder rice farmers with respect to participation on the platform (Table 10).

Among the identified ranked constraints, distance to the meeting place, confliction of meeting days with market days, poor dissemination of information regarding meeting days and risk were the top four most constraining factors of farmers' willingness to the MSP participation. Distance to the meeting place was found to be the most constraining factor of MSP participation. The success of the MSP is highly dependent on the location of the meeting place. The situation becomes aggravated where there is no access to transport services. Conflicting meeting days with market days was another major constraint to a successful willingness to participate on the platform. Most of the smallholder rice farmers are engaged in marketing activities either as sellers or buyers. Marketing of farm produce generates income for the household. Timely dissemination of information about meeting days was crucial to ensuring maximum participation on the platform. Season for holding meeting was the least identified constraint according to the respondents which indicated that the MSP meeting can be held during both the rainy and dry season.

\section{Conclusions and recommendations}

The study described multi-stakeholder platform participation based on key demographic indicators. There was high willingness of participation on the platform among smallholder rice farmers in Northern Ghana. The Probit regression analysis revealed that age of household head, household size and income were the main determinants of farmers' willingness to the MSP participation. Distance to meeting place was the most important constraint faced by the smallholder rice farmers in relation to their willingness to participate on the platform. Smallholder farmers residing at distant place from the meeting grounds were less likely to participate on the platform. The facilitators of the MSP must target and educate younger household heads within the region to ensure maximum participation and sustainability of the platform. Secondly, in designing of 
agricultural programmes, policy makers must incorporate activities that will impact positively on the income of farmers. Finally, the MSP must be situated at a central location coupled with improvements in road infrastructure in order to lessen the transportation burden of participants and consequently increase willingness of participation.

\title{
Endnotes
}

${ }^{a}$ Hubs represent key rice ecologies and different market opportunities across African countries, linked to major national or regional rice-development efforts to facilitate broader uptake of rice knowledge and technologies. It involves large groups of farmers and other value chain actors such as rice millers, input dealers and traders.

\begin{abstract}
Abbreviations
ABCs: Agricultural Business Centres; AfricaRice: Africa Rice Center; CAPAC: Cadinas Agricolas Productivas de Calidad; CDFO: Commercial Development of Farmer Based Organization; CFA: Financial Cooperation in Central Africa; CIRAD: Center for International Research in Agricultural Development; CONPAPA: Consorcio de Pequeños Productores de Papa, Consortium of Small Potato Producers; CSIR: Council for Scientific and Industrial Research; Df: Degrees of freedom; FASDEP: Food and Agriculture Sector Development Policy; FBO: Farmer-Based Organization; IPTA: Innovation platform for technology adoption; LR: Likelihood ratio; MCA: Millennium challenge account; MoFA: Ministry of food and agriculture; MSP: Multi-stakeholder platform; NGOs: Non-Government Organizations; SARI: Savanna Agricultural Research Institute; SRID: Statistical research and information directorate.
\end{abstract}

Competing interests

The authors declare that they have no competing interests both financial and non-financial.

\section{Authors' contributions}

This work was carried out in with the contribution from all listed authors. EM designed the study, performed the statistical analysis, and wrote the first draft of the manuscript. PME was in charge of the collection and management of the data. ANW managed and streamlined the analyses of the study and author WD managed the literature searches and edited the manuscript. All authors read and approved the final manuscript.

\section{Authors' information}

Edward Martey is an agricultural economist at the Savanna Agricultural Research Institute of the Council for Scientific and Industrial Research (CSIR-SARI), Nyankpala, Ghana.

\section{Acknowledgements}

The authors greatly acknowledged financial support by USAID and the smallholder rice farmers that voluntarily participated in the survey.

Received: 14 June 2014 Accepted: 23 June 2014

Published online: 24 July 2014

\section{References}

Adimado S (2001) Willingness to pay for research findings: a case study of pineapple farmers in Ghana. University of Ghana, Legon, Accra Ghana, pp 38-50, Unpublished MPhil Thesis Submitted, Department of Agricultural Economics and Agribusiness

Asante BO, Afari-Sefa V, Sarpong DB (2011) Determinants of small-scale farmers' decision to join farmer based organizations in Ghana. Afr J Agric Res 6(10):2273-2279

Ayamga M (2006) Factors influencing the decision to participate in microcredit programmes: an illustration for Northern Ghana. Ghana J Dev Stud 3(2):57-65

Coase RH (1937) The nature of the firm. Economica 4:386-405

Coase RH (1960) The problem of social cost. J Law Econ 3:1-44

Delgado C (1999) Sources of growth in smallholder agriculture in sub-Saharan Africa: the role of vertical integration of smallholders with processors and marketers of high value-added items. Agrekon 38(S1):165-89

Dorward A, Kydd J, Poulton C, Bezemer D (2009) Coordination risk and cost impacts on economic development in poor rural areas'. J Dev Stud 45(1):1-20

Edwards AL (1964) Statistical methods for the behavioural sciences. Holt, Rmehart and Wintson, New York, pp 402-410

Enete AA, Igbokwe EM (2009) Cassava market participation decision of household in Africa. Tropicultura 27(3):129-136

Etwire PM, Dogbe W, Wiredu AN, Martey E, Etwire E, Owusu RK, Wahaga E (2013) Factors influencing farmer's participation in agricultural projects: the case of the agricultural value chain mentorship project in the Northern Region of Ghana. J Econ Sustain Dev 4(No.10):36-43

Ghana Statistical Service, GSS (2008) Ghana living standards survey report of the fifth round (GLSS 5), Accra, Ghana. http://www.statsghana.gov.gh/docfiles/glss5_report.pdf

Gockowski J, Ndoumbe M (2004) The adoption of intensive monocrop horticulture in Southern Cameroon. J Agric Econ 30:195-202

Goetz S (1992) A selectivity model of household food marketing behavior in sub-Saharan Africa. Am J Agr Econ 74:444-52 
Greene HW (2003) Econometric analysis, 5th edn. Pearson Education, Inc., Upper Saddle River, New Jersey, USA Holloway G, Nicholson C, Delgado C, Staal S, Ehui S (2000) Agro-industrialization through institutional innovation, transaction costs, cooperatives and milk market development in the East African Highlands. Agr Econ 23(3):279-88

Key N, Sadoulet E, de Janvry A (2000) Transaction costs and agricultural household supply response. Am J Agr Econ 82(1):245-59

Kheralla M, Minet N, Kachule R, Souce BG, Berry P (2001) Impact of Agricultural Market Reforms on Smallholder Farmers in Benin and Malawi, Research Report, Vol. 2. IFPRI

Langyintuo AS, Mekuria M (2005) Accounting for neighborhood influence in estimating factors determining the adoption of improved agricultural technologies. A paper at American Agricultural Economics Association annual meeting, providence. Rode Island, pp 1-28

Makhura M, Kirsten J, Delgado C (2001) Transaction costs and smallholder participation in the maize market in the Northern Province of South Africa, Seventh Eastern and Southern Africa Regional Maize Conference, February, pp. 463-467. Agriculture in Ghana: Facts and Figures, Accra, Ghana

Markelova H, Meinzen-Dick R, Hellin J, Dohrn S (2009) Collective action for smallholder market access'. Food Pol 34:1-7

Martey E, Wiredu AN, Asante BO, Annin K, Dogbe W, Attoh C, Al-Hassan RM (2013) Factors influencing participation in rice development projects: the case of smallholder rice farmers in Northern Ghana. Int I Dev Econ Sustain 1(2):13-27

Mattson DE (1986) Statistics-Difficult Concept of Understanding Explanations'. Bolchanzy Carducci Publishers Inc, p 281, $283.361,423$

Ministry of Food and Agriculture, MoFA (2010) Agriculture in Ghana: facts and figures. Accra, Ghana, p 53

Mussei A, Mwanga J, Mwangi W, Verkuijl H, Mungi R, Elang A (2001) Adoption of improved wheat technologies by small-scale farmers in Mbeya District, Southern Highlands, Tanzania. International Maize and Wheat Improvement Centre (CIMMYT) and the United Republic of Tanzania, Mexico D.F

Nnadi FN, Akwiwu CD (2008) "Determinants of Youths' Participation in Rural Agriculture in Imo State, Nigeria". Journal of Applied Sciences 8(2): 328-333

Ofori IM (1973) Factors of agricultural growth in West Africa. ISSER, University of Ghana, Legon, Accra, Ghana

Olwande J, Mathenge M (2010) Market participation among the poor rural households in Kenya. Tegemeo Institute of Agricultural Policy and Development

Omamo SW (1998) Farm-to-market transaction costs and smallholder agriculture: Explorations with a non-separable household model. J Dev Stud 35:152-63

Pingali P, Meijer M, Khwaja Y (2005) Commercializing small farms: reducing transaction costs. www.ifpri.org/events/ seminars/SmallFarms/ Accessed 10 October 2007

Rölling N, Leeuwis C, Pyburn R (2002) Beyond the aggregation of individual preferences: moving from multiple cognition in resource dilemmas. In: Leeuwis $C$, Pyburn $R$ (eds) Wheelbarrows full of frogs: social learning in rural resource management. Koninklijke Van Gorcum, Assen, pp 25-47

Schultz TW (1945) Agriculture in an unstable economy. McGraw-Hill Book Company Inc, New York

Shepherd A (1997) Market information services: theory and practice. FAO (Food and Agriculture Organization), Rome

Southworth HM, Johnston BF (1967) Agricultural development and economic growth. Cornell University Press, UK

Stiglitz JE (1988) Economic organization, information and development. In: Chenery H, Srinivasan (eds) Handbook of development economics, vol. 1, chapter 5. Elsevier Science, Amsterdam

Thiele G, Devaux A, Reinoso I, Pico H, Montesdeoca F, Pumisacho M, Andrade-Piedra J, Velasco C, Flores P, Esprella R, Kurt Manrique T, Horton D (2011) Multi-stakeholder platforms for linking small farmers to value chains: evidence from the Andes". Int J Agr Sustain 423-433

Thiele G, Oros R, Velasco C, Ambrose K (2005) Por qué trabajar con plataformas? In: Thiele G, Bernet T (eds) Conceptos, Pautas y Herramientas. CIP, Lima, pp 66-70, 171

Vellema S, Ton G, Nakimbugwe D, Mwesige D, (2011) The Ugandan Oil Seed Sub-sector. Putting heads together: Agricultural innovation platforms in practice. ISBN 9789460221835. http://library.wur.n//WebQuery/wurpubs/426831

World Bank (2006) Where is the wealth of nations? Measuring capital for the 21st century. World Bank, Washington, DC

doi:10.1186/s40100-014-0011-4

Cite this article as: Martey et al:: Factors influencing willingness to participate in multi-stakeholder platform by smallholder farmers in Northern Ghana: implication for research and development. Agricultural and Food Economics 2014 2:11.

\section{Submit your manuscript to a SpringerOpen ${ }^{\circ}$ journal and benefit from:}

- Convenient online submission

Rigorous peer review

- Immediate publication on acceptance

- Open access: articles freely available online

- High visibility within the field

- Retaining the copyright to your article

Submit your next manuscript at $>$ springeropen.com 